\title{
CLIENTELISM \\ AND VOTING BEHAVIOR \\ Evidence from a Field Experiment \\ in Benin
}

\author{
By LEONARD WANTCHEKON*
}

\section{INTRODUCTION}

\begin{abstract}
COMPARATIVE politics scholars have long considered electoral politics in Africa to be systematically and inherently clientelist. African rulers, whether self-appointed or democratically elected, rely on the distribution of personal favors to selected members of the electorate in exchange for ongoing political support. ${ }^{1}$ This observation relies on the implicit assumption that African voters invariably have a much stronger preference for private transfers than for public goods or projects of national interest. This article reports on the use of experimental methods to test several hypotheses pertaining to electoral clientelism in Benin in order to investigate the determinants of the voters' demand for public goods.

The strategy consists of a unique field experiment organized in the context of the first round of the March 2001 presidential elections in Benin and in which randomly selected villages were exposed to "purely" clientelist and "purely" public policy platforms. The experiment is unique in the sense that it involves real presidential candidates compet-
\end{abstract}

\footnotetext{
*I would like to thank Kuassi Degboe, Mathias Hounkpe, Gregoire Kpekpede, Gilles Kossou, Herve Lahamy, Francis Laleye, the leaderships of the political parties involved in the experiment (RB, UDS, FARD-Alafia, and PSD), many others at the Institut National de la Statistique et de l'Analyse Economique and at the Institut Geographique National in Benin whose logistical support and assistance made the experiment possible. Thanks also to Jennifer Gandhi for superb research assistance, to Tamar Asadurian, Sophie Bade, Feryal Cherif, Donald Green, Paul Ngomo, Adam Przeworski, Melissa Schwartzberg, Susan Stokes, Carolyn Warner, and seminar participants at Stanford University for comments. Finally, special thanks to the Institution for Social and Policy Studies at Yale University for generous financial support and to Donald Green for continuous encouragement.

${ }^{1}$ See, among others, Robert Bates, Markets and States in Tropical Africa (Berkeley: University of California Press, 1982); Jean-François Bayart, L'Etat en Afrique: la politique du ventre (Paris: Fayard, 1989); C. James Scott, "Patron-Client Politics and Political Change in Southeast Asia," American Political Science Review 66 (March 1972); and Michael Bratton and Nicolas van de Walle, "Neopatrimonial Regimes and Political Transitions in Africa," World Politics 46 (July 1994).
}

World Politics 55 (April 2003), 399-422 
ing in real elections. To the best of my knowledge, it is the first ever nationwide experimental study of voter behavior involving real candidates using experimental platforms. A number of questions are considered. Given ethnic affiliation, does the type of message (clientelist or public policy) have an effect on voting behavior? Is clientelism always a winning strategy? Which types of message give incumbents or opposition a comparative advantage? Are female voters as likely as male voters to respond to clientelism? Are younger voters more likely than older voters to respond to clientelism?

Clientelism is defined as transactions between politicians and citizens whereby material favors are offered in return for political support at the polls. Thus, clientelism is a form of interest-group politics that has been the focus of a large body of literature in American and European politics. ${ }^{2}$ However, while the standard interest-group politics takes place in the context of organized competition among groups that could eventually lead to the representation of a variety of interests by one political party, clientelism is characterized by the representation of narrow corporatist and local interests. In addition, while the influence of interest groups tends to be filtered by the mechanisms of checks and balances, those mechanisms tend to be absent or ineffective in the context of clientelism. ${ }^{3}$

A large body of the comparative politics literature has investigated the nature of patron-client relationships, the inefficiency of various forms of clientelist redistribution, and conditions for its decay. The common conclusion is that clientelist politics is most attractive in conditions of low productivity, high inequality, and starkly hierarchical social relations. ${ }^{4}$ Others stress the importance of culture, historical factors, levels of economic development, and the size of the public sector economy. While studies of the social and economic determinants of

\footnotetext{
${ }^{2}$ For a review, see Bruce Cain, John Ferejohn, and Morris Fiorina, The Personal Vote: Constituency Service and Electoral Independence (Cambridge: Harvard University Press, 1997).

${ }^{3}$ Maurice Kugler and Howard Rosenthal, "Checks and Balances: An Assessment of the Institutional Separation of Powers in Colombia," Working Paper, no. 9 (Department of Economics and Econometrics, University of Southampton, 2000). According to Valeria Brusco, Marcelo Nazareno, and Susan Stokes, a clientelist model is characterized by present-oriented interaction, where people trade their votes for immediate payoffs such as rice, a steak, and a job; Brusco, Nazareno, and Stokes, "Clientelism and Democracy: Evidence from Argentina" (Paper presented at the Yale Conference on Political Parties and Legislative Organizations in Parliamentary Democracies, 2002) Thus, clientelism is contrasted with forward-looking choices over programs and backward-looking evaluation of past performance. In my view, clientelist electoral politics can involve as much forward-looking or backward-looking choices as does programmatic politics. In addition, for the purpose of the experiment, I focus on constituency services and patronage jobs instead of direct payment (rice, steak, or cash).

${ }^{4}$ For an analysis of the effects of income inequality, low productivity, and poverty on clientelism, see James Robinson and Thierry Verdier, "Political Economy of Clientelism," Working Paper (University of California, Berkeley, 2001).
} 
clientelism can help us understand its origins and derive some general conditions for its decline, they are not very helpful in explaining variance in the intensity of clientelist linkages within countries and the prevalence of clientelism in advanced and affluent democracies.

A parsimonious study of the impact of clientelism on voting behavior is important to social scientists for a variety of reasons. First, clientelism generates excessive redistribution at the expense of the provision of public goods, as politicians wastefully divert government resources to favored segments of the electorate. Second, since budgetary procedures in many countries either lack transparency or are discretionary, clientelism tends to favor those already in control of the government and therefore consolidates incumbency advantage in democratic elections. Such advantage and the ensuing decline in political competition could incite the opposition to political violence, thereby generating political instability and possibly the collapse of the democratic process. Third, a methodical study of electoral clientelism could reveal the existence of gender or generation gap(s), incumbency effects, and other results that could have important policy implications.

Consider, for example, the issue of a gender or generation gap. In a given region or within a given ethnic group, promise of government jobs might be less appealing to women than to men because men are more likely to be the beneficiaries. ${ }^{5}$ By contrast, electoral promises related to public health or child welfare such as vaccination campaigns could have a greater impact than patronage jobs on women's voting behavior. Income transfers could be less appealing to younger voters because such transfers disproportionately benefit older voters. In other words, younger voters or rural women might be systematically excluded from the most common forms of clientelist redistribution, and those groups might therefore be more responsive to a platform of public goods. This would imply that initiatives to promote women's participation in the political process at all levels of government are likely to help improve the provision of public goods.

On the supply side of clientelist goods, it could well be that incumbents are more credible about delivering on those goods than are opposition candidates. Such credibility could be enhanced if the incumbent has some discretion over distributive policies. Discretion over when and how to spend government resources allows the incumbent to undermine the credibility of opposition candidates by, for instance, making up-front payments to voters, as in the following example. Suppose that

\footnotetext{
${ }^{5}$ Government statistics indicate that in 1997 women in Benin represented only 18 percent of the low-level public sector workforce and 6 percent of the high-level public sector workforce.
} 
the incumbent wants to secure votes from a given district. Suppose that both the incumbent and the opposition make identical offers to voters at the political campaign stage, for example, for the government to hire five natives from the district. The incumbent could then spend some current government resources to hire two natives from the district and claim that he would hire three more if elected. Such a move clearly makes the incumbent more credible than the opposition: in the event of an opposition victory, the two native officials are likely to lose their jobs and the district might end up empty-handed, while an incumbent victory already guarantees two patronage jobs, with three more to follow after the election. In other words, the incumbent could use his discretionary power over current government spending to create a lock-in effect in resource allocation and dominate the opposition at the polls. ${ }^{6}$ In any case, if incumbency advantage over clientelism is empirically validated, it would imply that term limits and limited incumbent discretion on budgetary procedures would improve the delivery of public goods.

Another important question raised in the literature is the extent to which clientelism reinforces or weakens ethnic voting. In this article I investigate this question by selecting ethnically homogeneous experimental districts and measuring how much a candidate vote share would change if he were to switch from a clientelist platform to a broad public policy platform. The result provides a measure of the level of intensity of ethnic identity as well as of the strength of clientelist appeals. It is an important and novel exercise, since according to Kitschelt, "The rigorous operationalization of linkage mechanisms, particularly clientelism is absent from the comparative politics literature." In addition, survey methods do not provide reliable and unbiased measures of clientelism because it (clientelism) is perceived by most politicians and voters as morally objectionable. So we are left with subjective assessments of the intensity of clientelist appeals based on competing value judgments by social scientists. ${ }^{8}$

\footnotetext{
${ }^{6}$ For instance, a major government reshuffling took place during the two years preceding the 2001 elections with key portfolios such as Foreign Affairs, Economy, and Finances being allocated to natives of politically important districts such as Djougou in the Northwest and Ketou in the Southeast. Also, several government projects (construction of city halls, roads, schools, and so on) in a number of districts started a couple of months before the March 2001 election, with local representatives of the incumbent parties claiming openly that their completion is contingent on the outcome of the election.

${ }^{7}$ Herbert Kitschelt, "Linkages between Citizens and Politicians in Democratic Polities," Comparative Political Studies 33 (August-September 2000), 869.

${ }^{8}$ Kitschelt (fn. 7) suggests that we label a polity as clientelist if we find that programmatic parties are incohesive and the experts attribute high scores of corruption to that country (p. 871). This is clearly not a solution. Even if clientelism and corruption were correlated, they are two separate political categories. Moreover, current measures of corruption are subjective assessments by foreign investors and businessmen.
} 
The main contributions of this article are first to address key empirical questions pertaining to clientelist politics (like the ones discussed above) using unique experimental data and second to help provide an empirical foundation for the growing theoretical literature on redistributive politics and clientelism. The experiment empirically validates the view that electoral politics in Benin is dominated by clientelism. The results further develop and expand the conventional wisdom in African politics by establishing that (1) clientelist appeals reinforce ethnic voting (not the other way round) and that (2) voters' preference for clientelist or public goods messages depends in large part on political factors such as incumbency and on demographic factors such as gender. Before I describe the nature of the experiment and discuss the results and their relation to the literature, I briefly present some background information on electoral politics in Benin, followed by a discussion of the theoretical foundation of the experiment.

\section{The CONTEXT}

The Republic of Benin (former Dahomey) is located in West Africa between Togo and Nigeria with a southern frontage on the Atlantic Ocean. The majority of the country's population of 6,200,000 falls within four major ethnolinguistic groups: Adja in the Southwest, Yoruba in the Southeast, Fon in the South and Center, and Bariba in the North. Benin was colonized by France in 1894 and gained independence in 1960. The first twelve postindependence years were characterized by political instability and alternating civilian and military rule. The country experienced its fifth and last military coup in 1972. The coup paved the way for eighteen years of dictatorial regime led by Mathieu Kerekou.

In February 1990 mass protest and economic pressure by France led the military regime to convene a national conference (of representatives of all the political groups of that time) that gave birth to a democratic renewal. ${ }^{9}$ A transition government and parliament were created and a new constitution was written and approved by referendum, providing for a multiparty democracy. Since then Benin has experienced three parliamentary and two presidential elections. The president is elected through simple majority with runoff elections. ${ }^{10}$

\footnotetext{
${ }^{9}$ John R. Heilbrunn, "Social Origins of National Conferences in Benin and Togo," Journal of Modern African Studies 31 (June 1993); Kathryn Nwajiaku, "The National Conferences in Benin and Togo Revisited," Journal of Modern African Studies 32 (September 1994).

${ }^{10}$ That is, if no candidate reaches this majority during the first round, a second round is organized for the top two of the list and the one who gets the majority wins the election.
} 
The unicameral parliament consists of legislators elected under a system of closed-list proportional representation (the proportionality is per electoral district). The seats are distributed according to a district quotient that is obtained by dividing the votes effectively expressed per district by the district magnitude. Then the number of seats by a party or coalition of parties is obtained by dividing its vote by the district quotient; the remaining seats are allocated to the party or coalition with the largest remainder. A party or coalition of parties is allowed to take part in an election if it is able to present lists in every single electoral district. Since January 1999 the total number of seats in the parliament has been eighty-three, distributed over eighty-four electoral districts.

The country's first presidential election took place in 1991 and was won by Nicéphore Soglo, a former World Bank official. He was prime minister in the transition government that governed the country from 1990 to 1991 . The country had its second regular presidential contest on March 3, 1996, when Soglo lost to Mathieu Kerekou, the former autocrat. Kerekou won again in March 2001 for what will be his last term in office.

There are currently six main political parties in Benin, with three of them in the opposition coalition and the other three in the government coalition. The main government parties are the Action Front for Renewal and Development (FARD-Alafia) led by Saka Salley, which provides the main grassroots support for the current government in the northern region, the Social Democratic Party (PSD), which is led by Bruno Amoussou and based in the Southwest, and the Our Common Cause party led by Albert Tevoedjre and based in the Southeast. The opposition coalition comprises the Benin Renaissance party (RB) based in the southern and central regions and led by the former presidential couple Nicéphore and Rosine Soglo, the Union of Democracy and National Solidarity (UDS), led by Saka Lafia and based in the northeastern region, and finally the Party for the Democratic Renewal (PRD), led by the current National Assembly president Adrien Houngbedji and based in the southeastern region.

Benin presents a number of advantages for an experiment on clientelism. It is considered one of the most successful cases of democratization in Africa and has a long tradition of political experimentation. ${ }^{11}$

\footnotetext{
${ }^{11}$ For instance, the political leaders in Benin were the first to introduce the rotating presidency formula to curb ethnic strife in 1969. They also invented the national conference formula in 1989 as a way of facilitating a peaceful postauthoritarian transition. See Eboussi Boulaga, Les Conferences nationales en Afrique noire (Paris: Editions Karthala, 1993).
} 
Moreover and very important, the distribution of votes in previous elections was such that the risk of a field experiment seriously affecting the outcome of the 2001 election was nonexistent. This is because (1) the nationwide election outcomes have always revealed a significant gap between the top two candidates (Kerekou and Soglo) and the remaining candidates and (2) electoral support for those top two candidates has always been between 27 and 37 percent. ${ }^{12}$ As a result, a secondround election opposing Kerekou and Soglo in the 2001 presidential elections was a near certainty. This, together with the fact that the experiment took place mostly in the candidates' stronghold means the experiment is not risky for the parties, which explains why they agreed.

\section{EXPERIMENTAL DESIGN}

The analytical framework of the experiment is the standard model of redistributive politics developed by Lindbeck and Weibull, ${ }^{13}$ Dixit and Londregan, ${ }^{14}$ and more recently Lizzeri and Persico. ${ }^{15}$ There are three political actors in these models: two political parties and a set of citizens/voters. Parties can differ in their ideological position or their electoral platforms. The platforms can take the form of redistributive transfers to one or several groups of voters, the form of public goods provision, or both. Each voter has an ideological affinity for one of the parties, with the level of this affinity known only to the voter. Under these assumptions, electoral outcomes are uncertain and determined by the distribution of voters' ideological affinities and the parties' platforms. In this article, I simply replace ideological affinities with ethnic affinities and assume that citizens have ethnic affiliations or affinities and care about the fact that a member of their ethnic group or someone relatively close to their ethnic group is elected. The citizen might in fact also dislike the fact that a candidate from a specific ethnolinguistic origin is elected. The aim of this project is to measure the relative electoral gain or loss associated with campaign promises based on clientelism (transfer) as opposed to the ones based on public policy (public goods), given that voters have ethnic affinities.

\footnotetext{
${ }^{12}$ In 1991 Soglo obtained 27.2 percent of the vote, Kerekou obtained 36.30, and the next candidate, Tevoedjre, obtained 14.21 percent. In 1996 Soglo received 35.69 percent of the vote, Kerekou, 33.94 percent, and Houngbedji, 19.71 percent.

${ }^{13}$ Assar Lindbeck and Jorgen Weibull, "Balanced Budget Distribution as Outcome of Political Competition," Public Choice 52 (June 1987).

${ }^{14}$ Avinash Dixit and John Londregan, "The Determinants of Success of Special Interest in Redistributive Politics," Journal of Politics 58 (November 1996).

${ }^{15}$ Alessandro Lizzeri and Nicola Persico, "The Problem of Public Goods under Alternative Electoral Incentives," American Economic Review (March 2001).
} 


\section{EXPERIMENTAL DisTRICTS AND VILLAGES}

Voters in Benin are divided into eighty-four electoral districts, of which five or six are fairly competitive. Thus, for the purpose of the experiment, eight noncompetitive districts were selected. ${ }^{16}$ Of these eight, four were incumbent dominated and four were opposition dominated. In each noncompetitive district villages were partitioned into three subgroups. The first subgroup, composed of one village, was the clientelist treatment group, in which candidates were exposed to a clientelist message. The second subgroup, also composed of one village, was the public policy treatment group, in which voters were exposed to broad, nationally oriented messages. And the third subgroup was the control group; it was composed of the remaining villages of the district and both types of messages were run in it.

The main candidates competing in the election were Kerekou, the incumbent president endorsed by the FARD-Alafia, Amoussou Bruno from the PSD, Nicéphore Soglo from the RB, Saka Lafia from the UDS, and Adrien Houngbedji of the PRD. In order to take into consideration the regional competition between the opposition coalition and the incumbent coalition, I selected for the experiment Lafia and Kerekou (two northern candidates), and Soglo and Amoussou (two southern candidates). Kerekou and Soglo were the two leading candidates and national figures. With the help of a team of consultants, I contacted the leadership of the selected parties to secure their participation in the subsequent stages of the project. I define an experimentalist candidate as one who has been selected and has agreed to run an experimental political campaign in a given district.

In collaboration with the campaign managers of the four selected parties, past election results were used to identify the districts that were strongholds of each of the parties and districts that were competitive. A district is a stronghold of a party if the candidate endorsed by the party has won at least 70 percent of the votes in the two past presidential elections; otherwise, it is competitive. In addition a candidate is defined as a regional candidate if all of his strongholds are located in only one of the six provinces of the country. If his strongholds are located in at least two provinces, he is considered a national candidate. Thus, the national candidates are Kerekou and Soglo and the regional candidates are Lafia and Amoussou.

\footnotetext{
${ }^{16}$ Two competitive districts have also been selected. As I explain below, the procedures and the theoretical foundation of the experiment in those two districts are different from the ones in the noncompetitive districts.
} 
Among the six strongholds of FARD-Alafia, Kerekou, Kandi, and Nikki have been selected. Using the same procedure we have selected Perere and Bimbereke for UDS/Saka Lafia, Abomey-Bohicon and Pahou-Ouidah for RB/Soglo, and finally Aplahoue and Dogbo/ Toviklin for PSD/Amoussou. Two districts of competition (Come and Parakou) have been selected. Come is located in the Southwest, jointly controlled by Amoussou and Soglo; Parakou is located in the North and is jointly controlled by Kerekou and Lafia.

Two villages were selected within each experimental district. In any noncompetitive district one village was exposed to a clientelist platform, the other one to a public policy platform; the other villages of the district served as the control group. In a competitive district there were also two experimental villages. In the first village one candidate was running on clientelism while the other was running on public policy. The roles were reversed in the second village. As in the noncompetitive case, the remaining villages in the district served as the control group. All villages and districts involved in the experiment are defined as experimental or treatment villages and districts. The aggregate sample in the noncompetitive districts is 6,633 registered voters for clientelist villages, 6,983 voters for public policy villages, and 28,376 for the control group. The sample size of the experimental villages in the two competitive districts is 4,503 voters and about 80,000 for the control group.

Noncompetitive districts are ethnically homogenous and have the advantage of being less likely to be exposed to the regular, nonexperimental national campaign. They tend to have similar political and even demographic characteristics such as past electoral behavior, age, gender, education and income. Two randomly selected villages could therefore be perceived as identical, facilitating an identification of the treatment effect.

To ensure that those who were assigned to clientelism were not exposed to public policy and vice versa, sixteen of the twenty selected villages were at least twenty-five miles apart with seven to ten villages separating them. The remaining four were approximately five miles apart, separated by two to five villages. The risk of contagion between the two treatment groups was thereby minimized so that the two treatments remained mutually exclusive and uncorrelated. Table 1 presents the list of experimental districts and some of their political and demographic characteristics. The first column presents the districts, followed by the candidates, the villages, and the types of treatment. The final columns present the dominant ethnic groups.

Evaluating the treatment effect by simply comparing voting behavior 
TABLE 1

DESCRIPTION OF THE EXPERIMENTAL Districts

\begin{tabular}{|c|c|c|c|c|}
\hline District & $\begin{array}{c}\text { Exp. } \\
\text { Candidate }\end{array}$ & $\begin{array}{c}\text { Exp. } \\
\text { Villages }\end{array}$ & Treatment & Ethnicity \\
\hline \multirow[t]{2}{*}{ Kandi } & \multirow[t]{2}{*}{ Kerekou } & Kassakou & clientelism & Bariba (92\%) \\
\hline & & Keferi & public policy & Bariba (90\%) \\
\hline \multirow[t]{2}{*}{ Nikki } & \multirow[t]{2}{*}{ Kerekou } & Ouenou & clientelism & Bariba (89\%) \\
\hline & & Kpawolou & public policy & Bariba (88\%) \\
\hline \multirow[t]{2}{*}{ Bembereke } & \multirow[t]{2}{*}{ Saka Lafia } & Bembereke Est & clientelism & Bariba (86\%) \\
\hline & & Wannarou & public policy & Bariba (88\%) \\
\hline \multirow[t]{2}{*}{ Perere } & \multirow{2}{*}{ Saka Lafia } & Tisserou & clientelism & Bariba (93\%) \\
\hline & & Alafiarou & public policy & Bariba (94\%) \\
\hline \multirow[t]{2}{*}{ Abomey-Bohicon } & \multirow[t]{2}{*}{ Soglo } & Agnangnan & clientelism & Fon $(99 \%)$ \\
\hline & & Gnidjazoun & public policy & Fon $(99 \%)$ \\
\hline \multirow[t]{2}{*}{ Ouidah-Pahou } & \multirow[t]{2}{*}{ Soglo } & Acadjame & clientelism & Fon $(99 \%)$ \\
\hline & & Ahozon & public policy & Fon $(99 \%)$ \\
\hline \multirow[t]{2}{*}{ Aplahoue } & \multirow[t]{2}{*}{ Amoussou } & Boloume & clientelism & Adja (99\%) \\
\hline & & Avetuime & public policy & Adja (96\%) \\
\hline \multirow[t]{2}{*}{ Dogbo-Toviklin } & \multirow[t]{2}{*}{ Amoussou } & Dékandji & clientelism & Adja (99\%) \\
\hline & & Avedjin & public policy & Adja (99\%) \\
\hline \multirow[t]{2}{*}{ Parakou } & \multirow[t]{2}{*}{ Ker./Lafia } & Guema & competition & Bariba (80\%) \\
\hline & & Thiam & competition & Bariba (82\%) \\
\hline \multirow[t]{2}{*}{ Come } & \multirow[t]{2}{*}{ Am./Soglo } & Kande & competition & Adja (90\%) \\
\hline & & Tokan & competition & Adja (95\%) \\
\hline
\end{tabular}

of those in a clientelist treatment group and those in the public policy or the control group could lead to an underestimation of such an effect. This could be the case if voters who have been reached by campaign workers were more likely to favor one candidate or another. The effect is underestimated simply because only a fraction of the intent-to-treat group is actually treated. Following Gerber and Green's ${ }^{17}$ solution to similar problems in the context of their canvassing experiment, one could identify the treatment effect in a given district by subtracting the voting rate for the relevant candidate of, say, the clientelist village from the voting rate for the relevant candidate in the control villages and divide the difference by the observed contact rate.

\section{Design of EXPERIMENTAL Platforms}

Once the selection of the villages was complete, the different types of campaigns were designed with the active collaboration of the parties'

\footnotetext{
${ }^{17}$ Alan Gerber and Donald Green, "The Effects of Canvassing, Telephone Calls, and Direct Mail on Voter Turnout: A Field Experiment," American Political Science Review 94 (September 2000).
} 
campaign managers. It was decided that any public policy platform would raise issues pertaining to national unity and peace, eradicating corruption, alleviating poverty, developing agriculture and industry, protecting the rights of women and children, developing rural credit, providing access to the judicial system, protecting the environment, and/or fostering educational reforms. A clientelist message, by contrast, would take the form of a specific promise to the village, for example, for government patronage jobs or local public goods, such as establishing a new local university or providing financial support for local fishermen or cotton producers. Thus, the public policy message and the clientelist message would stress the same issues such as education, infrastructures development, and health care. But they would differ in that the former stressed the issue as part of a national program, or projet de société, while the latter stressed the issue as a specific project to transfer government resources to the region or the village. In addition, while national unity is a recurrent nationally oriented theme, the recurrent clientelist theme is government patronage jobs. ${ }^{18}$ Finally, it is worth stressing that a typical platform is a mixture of clientelist and public policy messages. For the purpose of the experiment, however, the parties have kindly offered to disentangle their platform in the experimental districts into one that is purely clientelist and one that is purely public policy. Thus, just as in any regular political campaign, the parties in the experiment were running on their own platforms. The only difference is that they have generously adapted the campaign messages that they intended to run in some villages to fit the objectives of the experiment. ${ }^{19}$

Following the design of the campaign messages, in December 2000 ten teams of campaign workers were created and trained at the Institut National de la Statistique et de l'Analyse Economique (INSAE), located in Cotonou, the commercial capital of the country. Each team had two members, one a party activist and the other a research assistant on the project with no party affiliation. The training consisted of the presentation of the goal of the project and an exposition of the different types of messages, as well as of various campaign techniques.

The training, monitoring, and supervision of the campaign workers

\footnotetext{
${ }^{18}$ Christopher Clapham defines government patronage jobs as the "common currency" of clientelism; Clapham, Patronage and Political Power (New York: St. Martin's Press, 1982).

${ }^{19}$ We could have differentiated the messages by opposing a purely clientelist message to a purely ethnic or religious message or to urban bias. However, neither religion nor urban bias is a salient political issue in Benin, as evidenced by the actual parties' platforms. In addition, purely ethnic messages would be too disconnected from the campaign strategies of the leading candidates (Kerekou and Soglo) and would be perceived as incitement to ethnic conflict.
} 
was provided by a four-member team of supervisors and consultants based at the INSAE. Two of the consultants were statisticians, and the other two had done graduate work in political science. They also served as intermediaries between the party leadership and the project.

Each district was assigned to a group of two activists, who ran clientelism in one experimental village and ideology in the other. For instance, the group in Kandi represented the FARD-Alafia and ran clientelism in Kassakou and public policy in Keferi. Assignment of activists to villages took into consideration their ethnic origin and their ability to speak the local languages. The activists sent individual weekly reports of their campaign activities to the team of supervisors. The team of supervisors also visited the campaign workers three times between January and March to make sure that the two types of treatment were not confused.

\section{Public Policy and Clientelist Treatments}

During each week for three months before the election, the campaign workers (one party activist and one social scientist) contacted voters in their assigned villages. With the help of the local party leader, they first settled in the village, contacted the local administration, religious or traditional authorities, and other local political actors. They then contacted individuals known to be influential public figures at home to present their campaign messages. They met groups of ten to fifty voters at sporting and cultural events. They also organized public meetings of fifty to one hundred people. On average, visits to households lasted half an hour and large public meetings about two hours.

A clientelist meeting took place in Tissierou on February 2, 2001. The meeting started with the following introduction by our local team: "We are the representatives of the candidate Saka Lafia, who is running for president in the March 3, 2001, election. As you know, Saka is the only Bariba candidate, actually the first since 1960. Saka is running because the northeast region, Borgou-Alibori, is very underdeveloped: low literacy rates, poor rural infrastructure and health care, etc. . . . If elected, he will help promote the interests of the Borgou-Alibori region, by building new schools, hospitals, and roads and more importantly, hiring more Bariba people in the public administration."

The following day, the team went to Alafiarou and held the public policy meeting: "We are representative of Saka Lafia, our party the UDS stands for democracy and national solidarity. Saka is running the opposition candidate in the North. If elected, he will engage in a nationwide 
reform of the education and health care system with emphasis on building new schools, new hospitals, and vaccination campaigns. In conjunction with other opposition leaders, we will fight corruption and promote peace between all ethnic groups and all the regions of Benin." The introductory statement was followed by a discussion period during which detailed explanations were provided on the public policy or clientelist platforms of the parties. ${ }^{20}$

Thus, a clientelist message highlighted the candidate's ethnic affiliation, singled out the interests of his region of origin, and promised pork barrel projects and patronage jobs. Meanwhile, a public policy message emphasized the candidate's affiliation with the incumbent or opposition coalition and outlined a socioeconomic and political project for the country. In order to avoid tensions among the activists participating in the project, we avoided attacks of the candidate's record or character as much as possible.

The local teams also provided information on alternative campaigns run in the experimental districts by nonexperimental candidates. For instance, the reports reveal that the main alternative campaign in Perere was run by Kerekou and was mostly nationally oriented.

\section{Data Collection and Empirical Results}

After the elections a survey was conducted in all ten experimental districts. In each district a representative sample of voters was interviewed in the clientelist village, the public policy village, and the control villages. The questionnaires are available upon request from the author. The data were collected in three main groupings. Questions were asked about demographic characteristics such as gender, marital status, education, and ethnic affiliation. There were also questions about the degree of exposure to messages. Finally, and perhaps more importantly, data were collected on voting behavior. For instance, questions were asked about turnout, knowledge of the main candidates, the rank order of the candidates, and voting behavior in the 2001 and 1996 presidential elections. Table 2 presents information about the survey, for ex-

\footnotetext{
${ }^{20}$ The evidence from the weekly reports by the activists suggests that programmatic meetings tend to last much longer than clientelist meetings. Some participants would criticize vote buying and electoral corruption by other candidates while others would want details on how the party's program would translate into specific promises for their districts. In response, the local team of activists would stress the need for a coordinated national development program. In clientelist meetings, participants would typically review past government projects implemented in their localities and make specific demands for the future.
} 
TABLE 2

Comparing Voting Behavior of Survey Respondents With Aggregate Voting Behavior in Experimental Districtsa ${ }^{a}$

\begin{tabular}{|c|c|c|c|c|c|c|}
\hline District & Candidate & Exp. Villages & $\begin{array}{l}\text { Reg. } \\
\text { Voters }\end{array}$ & $\begin{array}{c}\text { Sample } \\
\text { Size }\end{array}$ & $\begin{array}{l}\text { Sample } \\
\text { Mean }\end{array}$ & $\begin{array}{c}\text { Population } \\
\text { Mean }\end{array}$ \\
\hline \multirow[t]{3}{*}{ Kandi } & \multirow[t]{3}{*}{ Kerekou } & clientelist & 1133 & 61 & $1.00(0)$ & 0.81 \\
\hline & & public policy & 1109 & 60 & $0.49(.50)$ & 0.60 \\
\hline & & control & 3896 & 61 & $0.96(.18)$ & 0.75 \\
\hline \multirow[t]{3}{*}{ Nikki } & \multirow[t]{3}{*}{ Kerekou } & clientelist & 462 & 60 & $0.95(.21)$ & 0.90 \\
\hline & & public policy & 1090 & 60 & $0.93(.24)$ & 0.85 \\
\hline & & control & 2979 & 60 & $0.95(.20)$ & 0.82 \\
\hline \multirow[t]{3}{*}{ Bembereke } & \multirow[t]{3}{*}{ Lafia } & clientelist & 999 & 60 & $0.92(.26)$ & 0.94 \\
\hline & & public policy & 931 & 60 & $0.89(.30)$ & 0.93 \\
\hline & & control & 5204 & 61 & $0.91(.28)$ & 0.74 \\
\hline \multirow[t]{3}{*}{ Perere } & \multirow[t]{3}{*}{ Lafia } & clientelist & 657 & 59 & $0.76(.42)$ & 0.81 \\
\hline & & public policy & 442 & 60 & $0.13(.33)$ & 0.25 \\
\hline & & control & 4477 & 61 & $0.52(.40)$ & 0.58 \\
\hline \multirow[t]{3}{*}{ Abomey } & \multirow{3}{*}{ Soglo } & clientelist & 1172 & 60 & $0.98(.13)$ & 0.91 \\
\hline & & public policy & 1199 & 60 & $0.98(.13)$ & 0.90 \\
\hline & & control & 5204 & 61 & $0.74(.15)$ & 0.86 \\
\hline \multirow[t]{3}{*}{ Ouidah } & \multirow[t]{3}{*}{ Soglo } & clientelist & 321 & 60 & $0.93(.25)$ & 0.86 \\
\hline & & public policy & 701 & 61 & $0.92(.26)$ & 0.72 \\
\hline & & control & 2414 & 60 & $0.73(0.44)$ & 0.64 \\
\hline \multirow{3}{*}{ Aplahoue } & \multirow[t]{3}{*}{ Amoussou } & clientelist & 492 & 59 & $0.98(.13)$ & 0.87 \\
\hline & & public policy & 511 & 60 & $0.91(.28)$ & 0.77 \\
\hline & & control & 4037 & 61 & $0.98(.20)$ & 0.72 \\
\hline \multirow[t]{3}{*}{ Dogbo } & \multirow[t]{3}{*}{ Amoussou } & clientelist & 1397 & 60 & $0.64(.48)$ & 0.65 \\
\hline & & public policy & 736 & 61 & $0.50(.50)$ & 0.47 \\
\hline & & control & 1161 & 59 & $0.45(0.44)$ & 0.84 \\
\hline
\end{tabular}

${ }^{a}$ The vote choice variable takes the value 1 if the voter of a given type (male or female) chooses a candidate of a given type (for example, northern or southern) running experimental platforms in his or her district and 0 otherwise.

ample, sample size and comparison of voting behavior among respondents and actual aggregate voting behavior in the experimental districts and the control villages. ${ }^{21}$ The means reported in Table 2 (also in Tables 3 and 4 below) are calculated by using a vote choice variable that takes a value of 1 if the voter votes for the experimentalist candidate running a campaign in the district, 0 otherwise. For example in Abomey, the choice variable takes the value 1 if the voter chooses Soglo and 0 otherwise.

\footnotetext{
${ }^{21}$ The confidence interval of the village sample means indicate that the samples of respondents are fairly representative of the voting population.
} 


\section{ESTIMATION OF TREATMENT EFFECTS}

Random or near-random assignment of villages to treatments makes the empirical strategy fairly straightforward. The average treatment effect could be obtained by comparing the mean of voting behavior in each treatment group with the mean in the control group. More precisely, define by $y_{k}$ a measure of the vote for candidate $k$ in a given district, where $0 \leq y_{k} \leq 1$. Define by $C L, P B$, and $C$ dummy variables that take values 1 if the voter is clientelist, public policy, and control group respectively, and $O$ otherwise. Let $\hat{\mathrm{E}}($.) be the estimated conditional mean of $y_{k}$. The clientelist treatment effect is given by

$$
\hat{\mathrm{E}}\left(y_{k} \mid C L=1\right)-\hat{\mathrm{E}}\left(y_{k} \mid C=1\right)
$$

and similarly for the public policy treatment effect.

The difference-in-means procedure is followed by a probit analysis that helps check its robustness. The main dependent variable is vote for a type of candidate (national versus regional, northern versus southern, incumbent versus opposition). The main independent variables are gender, age, past voting behavior, and types of treatment.

The empirical analysis is based on the data collected in the eight noncompetitive districts. This is because the candidates involved in the experiment in those districts fully complied with the procedures of the experiment and outside or nonexperimental influence on voters in those areas was very limited. By contrast, compliance was only partial in the two competitive districts, with outside influence in those areas significant and sometimes overwhelming. ${ }^{22}$

To compute the treatment effects, I first use the actual vote returns in the districts involved in the experiment presented in Table 2. The results indicate positive treatment effects in each individual district, except Dogbo. On aggregate, the mean of voting returns for experimentalist candidates (with standard deviation in parentheses) in the clientelist villages, public policy villages, and control villages are respectively 0.84 $(0.05), 0.69(0.30)$, and $0.74(0.25)$. The results thus indicate a positive clientelist treatment effect on average. The public policy treatment effect is on average negative, though it is positive in some individual districts, for example, Ouidah and Abomey.

Table 3 presents the results of estimation using the survey data. The results also indicate a significant and positive clientelist treatment effect for all candidates. In addition, there is a significant and negative

\footnotetext{
${ }^{22}$ This was the case, for example, in Come, where the dominant campaign was run by Kerekou, a nonexperimental candidate in that district.
} 
TABLE 3

Difference in Means between Treatment and Control VILLAGES FOR EACH TyPE OF CANDIDATE ${ }^{a}$

\begin{tabular}{|c|c|c|c|c|c|}
\hline $\begin{array}{l}\text { Type of } \\
\text { Candidate }^{\mathrm{b}}\end{array}$ & Public & Clientelist & Control & $\begin{array}{l}\text { Public- } \\
\text { Control }\end{array}$ & $\begin{array}{c}\text { Clientelist- } \\
\text { Control }\end{array}$ \\
\hline Northern & $\begin{array}{l}.322(.032) \\
208\end{array}$ & $\begin{array}{l}.674(.032) \\
218\end{array}$ & $\begin{array}{l}.565(.035) \\
200\end{array}$ & -.24 & $.109(.047)^{* *}$ \\
\hline Southern & $\begin{array}{l}.840(.025) \\
219\end{array}$ & $\begin{array}{l}.890(.021) \\
228\end{array}$ & $\begin{array}{l}.741(.029) \\
224\end{array}$ & $.099(.039)^{* * * *}$ & $.149(.036)^{* * * *}$ \\
\hline Incumbent & $\begin{array}{l}.693(.032) \\
202\end{array}$ & $\begin{array}{l}.897(0.21) \\
214\end{array}$ & $\begin{array}{l}.835(.027) \\
194\end{array}$ & $-.141(.042)^{* * *}$ & $.062(.033)^{*}$ \\
\hline Opposition & $\begin{array}{l}.493(.033) \\
225\end{array}$ & $\begin{array}{l}.681(.033) \\
232\end{array}$ & $\begin{array}{l}.509(.031) \\
230\end{array}$ & $-.015(.047)$ & $.172(.045)^{* * * *}$ \\
\hline Local & $\begin{array}{l}.385(.032) \\
226\end{array}$ & $\begin{array}{l}.603(.033) \\
224\end{array}$ & $\begin{array}{l}.509(.033) \\
230\end{array}$ & $-.124(.046)^{* * *}$ & $.094(.047)^{* * *}$ \\
\hline National & $\begin{array}{l}.816(.027) \\
201\end{array}$ & $\begin{array}{l}.968(.012) \\
222\end{array}$ & $\begin{array}{l}.835(.027) \\
194\end{array}$ & $-.019(.038)$ & $.133(.028)^{* * * *}$ \\
\hline
\end{tabular}

**** significant at $99 \%$; ${ }^{* *}$ significant at $95 \%$, * significant at $90 \%$

${ }^{a}$ The first column presents the types of candidates; the following three columns present the means of voting behavior in the public policy and the clientelist treatment groups and the control groups, respectively. Sample sizes are indicated right below the means, and standard errors are in parentheses. The last two columns present the public policy treatment effect and the clientelist treatment effect. The vote choice variable takes the value 1 if the voter of a given type (male or female) chooses a candidate of a given type (for example, northern or southern) running experimental platforms in his or her district and 0 otherwise.

${ }^{\mathrm{b}}$ Northern is Kerekou, Lafia; southern is Soglo, Amoussou; incumbent is Kerekou, Amoussou; opposition is Soglo, Lafia; national is Kerekou, Sogolo; regional is Amoussou, Lafia.

public policy treatment effect for northern candidates, regional candidates, and incumbent candidates. By contrast, there is a positive treatment effect for southern candidates. A direct comparison of the treatment effects - that is, of clientelism versus control (not shown)reveals that clientelism is more effective for northern candidates.

\section{GENDER GAP}

Table 4 presents voting behavior by gender for each group of candidates. Under public policy treatment, the difference in means of voting behavior between female and male is positive and significant for the northern candidates (0.261) and for national candidates (0.306). Women have a stronger preference for the opposition candidates in both treatment groups. However, the effect is stronger in the public policy treatment group (0.382) than in the clientelist treatment group (0.186). 


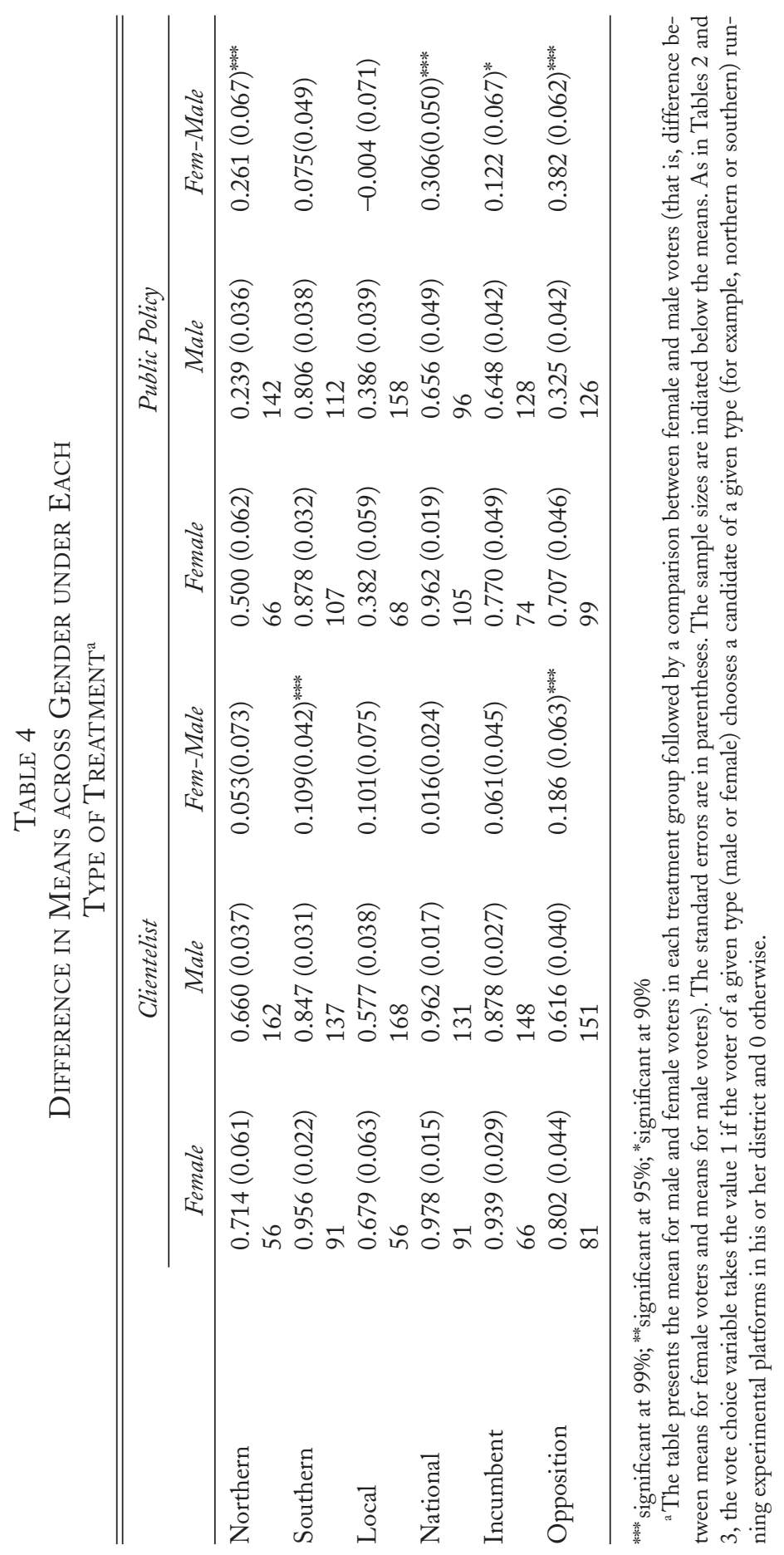


District-level breakdown (not shown) suggests that gender gap under public policy treatment was apparent in the two experimental districts where Soglo ran. In Abomey-Bohicon the candidate had slightly lower electoral support with men in the public policy village than in the clientelist village. In Ouidah (Soglo's other stronghold) women's support for the candidate remains strong in both treatment villages ( 0.97 in the clientelist village and 1.00 in the public policy village).

\section{PROBIT ANALYSIS}

I now provide a more comprehensive analysis of the treatment effect with multivariate analysis. The analysis provides an estimation of the treatment effect by controlling for past voting history and other variables.

For the basic specification, I assume that the variable measuring the expected utility of voter $i$ when he or she votes for $k$ in the current election can be modeled as

$$
\mathrm{y}^{\mathrm{i}^{*} \mathrm{i}, \mathrm{k}}=\alpha+\beta \mathrm{X}_{\mathrm{i}}+\lambda \mathrm{y}_{\mathrm{i}, \mathrm{k}}^{0}+\gamma \mathrm{CL}_{\mathrm{k}}+\delta \mathrm{PB}_{\mathrm{k}}+\varepsilon_{\mathrm{i}}
$$

The variable $\mathrm{y}^{1^{*}}{ }_{\mathrm{i}, \mathrm{k}}$ is not observable. However, one observes that

$$
\mathrm{y}_{\mathrm{i}, \mathrm{k}}^{1}=1 \text { if } \mathrm{y}^{1^{*}}{ }_{\mathrm{i}, \mathrm{k}}>0 \text { and } \mathrm{y}_{\mathrm{i}, \mathrm{k}}^{1}=0 \text { if } \mathrm{y}^{1^{*}, \mathrm{k}} \leq 0 \text {. }
$$

where $\mathrm{y}_{\mathrm{i}, \mathrm{k}}^{1}=1$ means that $i$ voted for $k$, and 0 otherwise. For instance the variable Northern takes the value 1 if the respondent voted for Kerekou in Kerekou's experimentalist districts or the respondent voted for Lafia in Lafia's experimentalist district, and 0 otherwise. $\mathrm{X}_{\mathrm{i}}$ is a vector of individual traits such as gender, and age, that is, $X=\{\mathrm{AGE}$, SEX where SEX denotes the gender of the voter and takes the value 1 if the voter is male and 0 if she is female. AGE is continuous variable.

The crucial independent variables are past voting behavior and treatment (clientelist, public policy). To control for past voting behavior, I include $\mathrm{y}_{\mathrm{i}, \mathrm{k}}^{0}$ which is a dichotomous independent variable taking the value 1 if the individual voted for the experimentalist candidate in the 1996 presidential elections, 0 otherwise.

To evaluate the treatment effect, I use the variables $\mathrm{CL}_{\mathrm{k}}, \mathrm{PB}_{\mathrm{k}}$ and $\mathrm{C}_{\mathrm{k}}$ that take the value 1 if the voter is in the clientelist, public policy, and control group of candidates $\mathrm{k}$ respectively, and 0 otherwise. In order to test the existence of gender gap(s), I introduce the variable $\mathrm{SEX}_{\mathrm{i}}^{*} \mathrm{CL}_{\mathrm{k}}$ and $\mathrm{SEX}_{\mathrm{i}}^{*} \mathrm{~PB}_{\mathrm{k}}$. 
TABLE 5

Probit Analysis of Vote for Type of Candidates in

TREATMENT Villages

\begin{tabular}{lcccccc}
\hline \hline & Southern & Northern & Local & National & Incumbent & Opposition \\
\hline Constant & $-0.946^{* *}$ & -0.513 & -0.367 & -0.741 & -0.186 & 0.222 \\
& $(0.395)$ & $(0.374)$ & $(0.306)$ & $(0.469)$ & $(0.415)$ & $(0.271)$ \\
Sex & $-0.513^{*}$ & $-0.516^{* * *}$ & -0.424 & $-0.828^{* *}$ & -0.415 & 0.024 \\
& $(0.200)$ & $(0.194)$ & $(0.330)$ & $(0.332)$ & $(0.370)$ & $(0.231)$ \\
Age & 0.006 & -0.003 & $-0.009^{*}$ & $0.011^{*}$ & 0.004 & 0.002 \\
& $(0.006)$ & $(0.005)$ & $(0.005)$ & $(0.006)$ & $(0.006)$ & $(0.005)$ \\
Past & $2.139^{* * *}$ & $.865^{* * *}$ & $1.555^{* * *}$ & $2.057^{* * *}$ & $1.893^{* * * *}$ & $0.966^{* * *}$ \\
& $(0.203)$ & $(0.235)$ & $(0.201)$ & $(0.271)$ & $(0.180)$ & $(0.215)$ \\
Public policy & $0.309^{* *}$ & $-0.372^{* * *}$ & $-0.594^{*}$ & 0.429 & -0.287 & $0.512^{*}$ \\
& $(0.333)$ & $(0.365)$ & $(0.318)$ & $(0.427)$ & $(0.387)$ & $(0.290)$ \\
Clientelist & $1.004^{* *}$ & 0.264 & 0.444 & 0.550 & 0.344 & $0.754^{* *}$ \\
& $(0.447)$ & $(0.391)$ & $(0.342)$ & $(0.457)$ & $(0.468)$ & $(0.319)$ \\
Sex*Client. & -0.502 & -0.191 & -0.348 & 0.489 & 0.208 & -0.324 \\
& $(0.505)$ & $(0.435)$ & $(0.379)$ & $(0.548)$ & $(0.539)$ & $(0.364)$ \\
Sex*Public Pol. & 0.167 & $-1.050^{* *}$ & 0.147 & -0.572 & -0.111 & $-0.773^{* *}$ \\
& $(0.402)$ & $(0.414)$ & $(0.358)$ & $(0.482)$ & $(0.450)$ & $(0.345)$ \\
N & 524 & 543 & 596 & 510 & 472 & 602 \\
log-L & -145.250 & -208.538 & -284.0500 & -115.986 & -146.161 & -244.583 \\
\hline
\end{tabular}

*** significant at $99 \%$; * significant at $95 \%$; * significant at $90 \%$

Table 5 presents the results. Public policy treatment effect is positive and significant in the South and for the opposition candidate but negative and significant in the North and for regional candidates. The interaction effect Sex and public policy is negative in the North and for opposition. The joint significance (Wald) test indicates that $\mathrm{CL}_{k}$ together with $\mathrm{SEX}^{*} \mathrm{CL}_{\mathrm{k}}$ is significant for all types of candidates except for regional and northern candidates. Further, $\mathrm{PB}_{\mathrm{k}}$ together with $\mathrm{SEX}^{*} \mathrm{~PB}_{\mathrm{k}}$ is significant for all except candidates national and opposition. Finally, the AGE variable is insignificant in all regressions except for regional candidates and national candidates and PAST is positive and significant for all types of candidates.

Overall, the following results are significant in both the differencein-means and the probit analysis: (1) negative public policy treatment effect in the North and district controlled by regional candidates, (2) positive public policy treatment effect in the South, (3) positive public policy treatment effect on women in the North and in oppositioncontrolled districts (which are mostly in the South), (4) positive clien- 
telist treatment effect for all types of candidates, though not significant in the probit analysis for the regional candidates and northern candidates (which is rather anomalous). ${ }^{23}$

Why are public policy messages less effective in the North and in districts controlled by regional candidates? Why would such messages be more effective in the South and in districts controlled by the opposition? Why would women be more receptive than men to public policy messages and to opposition candidates?

One natural explanation for the negative public policy treatment in the North could be that the region is poorer than the South. However, such an explanation is not consistent with existing evidence on regional disparities. Indeed, official government data compiled by the Institute of Statistics and Economic Analysis (INSAE) suggest that in 2000, life expectancy in Borgou (the northern province where the experiment took place) was eleven years higher than in Zou, the corresponding southern province. The data also suggest that from 1997 to 2000 Borgou did at least as well as Zou in terms of telephone connections, educational outcomes, and public health. ${ }^{24}$

In my view, the most plausible explanation is that Borgou is dominated by regional parties (UDS and FARD) while Zou is dominated by a national opposition party, the RB, and national opposition parties are more credible than regional parties on broad-based public policy. In other words, the regional gap between Zou and Borgou could simply be a reflection of the credibility gap between the UDS and the RB on national issues.

As for the gender gap result, there are two potential explanations. The first is that because women are excluded from the most common forms of redistribution, they are more responsive to platforms stressing public health or education reforms. The second explanation is occupational choice. Fachchamps and Gabre-Madhin indicate that while men dominate agricultural production, 80 percent of interregional traders in Benin are women. ${ }^{25}$ Thus, a significant proportion of rural women travel weekly to other regions of the country and speak several languages. Those women are likely to be better informed about social and

\footnotetext{
${ }^{23}$ The district-level breakdown indicates that clientelism was very effective in Perere, a district controlled by Lafia, a regional candidate.

${ }^{24}$ See Institut National de la Statistique et de l'Analyse Economique, Tableau de Bord Social (Cotonou, Benin : Publication gouvernementale, 2000). Another possible explanation could be that the North is more ethnically homogeneous than the South. However, the evidence suggests that the two provinces have a nearly identical degree of ethnic homogeneity (92 percent).

${ }^{25}$ Marcel Fafchamps and Elini Gabre-Madhin, "Agricultural Markets in Benin and Malawi," Working Paper 2734 (Washington, D.C.: World Bank, Development Research Group, 2001).
} 
economic conditions in the country than male voters and will tend to value broad-based public policy.

The fact that past electoral behavior is a good predictor of current voting behavior is not surprising, given the strength of ethnic affiliation and voting. In almost all districts the candidate who dominated in previous elections retained much of his core electorate. The only major exception was in Perere, where the Kerekou electorate (mostly from the Bariba ethnic group) melted away when a Bariba candidate, Lafia, entered the race. The postelection survey data suggest that Lafia's supporters were not strategic: nearly all Lafia's voters thought everybody else was voting for Kerekou!

The positive effect of clientelist messages delivered by regional candidates also indicates that ethnic identity does not entirely determine voting behavior. Types of platforms and method of voter mobilization also matter. For instance, political support for Lafia in his native district of Perere dropped significantly when he switched from clientelism to public policy. ${ }^{26}$

\section{RELATION TO THE LITERATURE}

The theoretical foundation of the present article follows analyses of distributive politics by Lindbeck and Weibull ${ }^{27}$ and Dixit and Londegran. ${ }^{28}$ The articles allow for public good, in the form of the ideology of the party elected. The literature is vague, however, about the nature of the public good and how it is produced. ${ }^{29}$ In addition, the models do not differentiate between incumbent and challenger, between national and regional candidates. They also do not discuss the potential comparative advantage that candidates might have over redistribution or public policy promises. The empirical results presented here suggest that more realistic models should explicitly include incumbency and the scope of the competing candidates.

\footnotetext{
${ }^{26}$ In a recent study of electoral clientelism in Benin, Richard Banegas finds that politicians consistently engage in vote buying and that voters come to expect these largesses and actually use them to assess their likely postelection generosity; Banegas, La Démocratie à pas de caméléon (Paris: Editions Karthala, 2002). One might thus conclude that the negative impact of the nationally oriented message was a reflection of voters considering such a message as suspicious and unusual. However, there is evidence suggesting that political campaigns of all the major candidates have always involved many national themes such as corruption eradication, women's rights, and educational reform. Thus an experimental platform stressing those themes should not have been perceived as unusual, and we find no evidence from the field suggesting otherwise.

${ }^{27}$ Lindbeck and Weibull (fn. 13).

${ }^{28}$ Dixit and Londregan (fn. 14).

${ }^{29}$ Avinash Dixit and John Londregan, "Ideology, Tactics, and Efficiency in Redistributive Politics," Quarterly Journal of Economics 113 (May 1998).
} 
Women's inclination toward public policy echoes a recent study by Chattopadyay and Duflo. ${ }^{30}$ The authors examine the policy implications of an affirmative action type of reform in India in which seats are set aside for women in a number of randomly chosen local governments. Chattopadyay and Duflo compared the types of policies implemented in reserved and unreserved village councils and found a significant gender gap in types of policies implemented. ${ }^{31}$ They found, in particular, that while women tend to invest in infrastructure directly relevant to the needs of rural women such as water, fuel, and road composition, men tend to invest more in education. The context of the present study is not a local government but a national government, and the strategies of the politicians involved in the experiment are not types of public goods but instead are clientelist goods versus public goods. Moreover, in the present study women are not in the position of decision makers. They are instead voters.

Lemarchand argues that ethnicity should be studied independently from clientelism, because "whereas clientelism describes a personalized relationship, ethnicity is a group phenomenon, therefore there is no compelling reason to expect concomitant variations between ethnic solidarities and client-patron solidarities." ${ }^{32}$ Ethnic solidarities, therefore, can either conflict with or reinforce patron-client solidarities. The distinction between the two types of relationships is illustrated by the significant intraethnic variance in preferences for clientelist goods. In addition, the positive response to clientelist appeals by regional or ethnic candidates may indicate that ethnic solidarities can help enforce clientelist bargains.

The methodology of this study is part of an emerging literature on experimental field research in the social sciences. An experiment is a purposeful intervention to alter a social environment in a specific way, to compare the outcomes in the experimental group(s) and the control groups, and to derive the impact of a variable of interest. Fisher presents a general treatise on experiments with random assignments. ${ }^{33}$ It is argued that when subjects are drawn randomly and formed into treatment groups, and when the subjects are assigned to receive the same treatment, then the distribution of outcomes should be the same as in an experiment in which the whole population received the treatment.

\footnotetext{
${ }^{30}$ Raghabendra Chattopadyay and Esther Duflo, "Women's Leadership and Policy Decisions: Evidence from a National Randomized Experiment in India," Working Paper (Cambridge: MIT, 2001).

${ }^{31}$ Ibid.

${ }^{32}$ René Lemarchand, "Political Clientelism and Ethnicity in Tropical Africa: Competing Solidarities in Nation-Building," American Political Science Review 66 (March 1972).

${ }^{33}$ Ronald Fisher, The Design of Experiments (London: Oliver and Boyd, 1935).
} 
Randomized field experiments in political science have focused on studying how various techniques of voter mobilization (mail, canvass, telephone) affect voter turnout. ${ }^{34}$ Gerber and Green argued that these studies were severely limited by small sample sizes and by flawed econometric techniques that did not account for the fact that some subjects assigned to treatments were not contacted. ${ }^{35}$ Their study of voter mobilization in New Haven overcame these limitations by increasing the number of subjects involved in the experiment from about 3,969 in the Gosnell experiment to 30,000 and by using the method of instrumental variables to correct for potential bias in the estimation of the treatment effect that might result from the fact that subjects who were easier to contact might have a higher propensity to vote.

The present study differs from previous experimental studies in a number of ways. First, the dependent variable is voting behavior not voter turnout, and the treatment is political platforms not mobilization techniques. Second, the data generated by the experiment (political attributes of the parties, personal attributes of voters) help identify treatment effects associated with various types of candidates (incumbent and opposition, regional and national). The data also help identify treatment effects in a variety of settings, for example, the northern districts or southern districts, or across demographic groups, for example, male versus female.

\section{CONCLUSION}

This article reports on a randomized field experiment designed and implemented in the context of the first round of the 2001 presidential elections in Benin in order to provide a nuanced and parsimonious investigation of the impact of clientelism on voting behavior. The empirical results show that clientelism works for all types of candidates but particularly well for regional and incumbent candidates. The results indicate that women voters have stronger preference for public goods than do men and that younger and older voters have similar policy preferences. I argue that credibility of clientelist appeals and accessibility of clientelist goods greatly influence voting behavior.

\footnotetext{
${ }^{34}$ Harold Grosnell, Getting Out the Vote: An Experiment in the Stimulation of Voting (Chicago: University of Chicago Press, 1927); Samuel J. Elderveld, "Experimental Propaganda Techniques and Voting Behavior," American Political Science Review 50 (March 1956); William C. Adams and Dennis Smith, "Effects of Telephone Canvassing on Turnout and Preferences: A Field Experiment," Public Opinion Quarterly 44 (Autumn 1980); Roy E. Miller, David Bositis, and Denise Baer, "Stimulating Voter Turnout in a Primary with a Precinct Committeeman," International Political Science Review 2, no. 4 (1981); and more recently Gerber and Green (fn. 17).

${ }^{35}$ Gerber and Green (fn. 17).
} 
For instance, incumbent candidates have the means to make clientelist appeals more credible by delivering a part of the promised goods before the election. Opposition candidates can take advantage of the revealed incompetence of the incumbent in providing the public goods during the previous electoral cycle to make its public goods-type promises more appealing and more credible. Finally, because most clientelist-type policies disproportionately benefit men over women or because rural women might value child welfare policies more highly than men do, women are more likely than men to have preference for public goods.

The gender gap results in the opposition-controlled districts of Abomey-Bohicon and Ouidah-Ahozon could have been more significant if we had selected weaker opposition strongholds, that is, districts with a larger number of marginal opposition supporters. However, this would have increased the risk of the experiment affecting the election outcomes and therefore have made the collaboration of the parties less likely. Thus, further experiments are needed to check the robustness of the results. In addition, since the current project took place mostly in rural districts and in the context of presidential elections, it would be useful to extend the experiment to include more urban districts, other types of elections (legislative and municipal), and perhaps other countries.

Despite the limitations of the experiment, the results discussed here indicate quite clearly and rigorously that voting behavior is far from being entirely determined by ethnic affiliation and, more importantly, that clientelist appeals - even if they are strong in many cases-are not universally accepted even among poor voters and at low levels of economic development. 